\title{
Language Maintenance Of Dryland Farming Lexicon In Dawan Language: Eco-Linguistics Analysis
}

\author{
Nila Puspita Sari \\ \{nilapuspita@unimor.ac.id\} \\ University of Timor NTT, Indonesia
}

\begin{abstract}
Modernization and heterogeneity of language speaker become an indicator in making language shifting especially in local language as identity in one region. This research aims at analyzing language maintenance by young speaker of Dawan language using region, the local call themselves Atoin Meto. Data was taken by using direct observation and structured interview of sixty dryland farming lexicons to Dawanese young speakers who live in Kefamenanu and Soe. Data analysis showed that most of subjects especially in Kefamenanu used in this research have no idea about lexicons in dryland farming firstly related to lexicons about plantation and wood ecosystem. The responds are vary, which is because of less reference related to them and also most of them used Indonesian and even Kupang in their daily. Moreover, it becomes logic because Kefamenanu as the capital city of Timor Tengah Utara regency becomes the center of construction where most of plantation and farming area were destructed for making living or housing area. It affected the loss of ecosystem both plantation and farming which also affect the loss of source can be identified by young generation. Furthermore, lexicons related to both ecosystem became unfamiliar due to the loss of reference. Based on that phenomena, it can be concluded that the destruction of an ecosystem gave significant effect to the language maintenance in certain region, and it should get more attention.
\end{abstract}

Keywords - Ecolinguistics, dryland farming, language maintenance

\section{Introduction}

The incessant use of Indonesian as a communication tool in the formal environment has shifted the role of regional languages as the main communication tool. Indonesian Language becomes main language that is used in whole social life, not least for the people who inhabit the Timor Tengah Utara (TTU) regency, where this region has Dawan as a regional language, which is now increasingly being used, especially among the younger generation or students. Based on direct observations of students in the scope of the University of Timor, where the majority of students are people who inhabit the TTU region and the districts around it, such as Timor Tengah Selatan (TTS), Malaka, Atambua even from the island of Flores, the use of 
Indonesian and Kupang Malay is increasingly being used. Temporary assumption could be due to heterogeneity of students with their respective cultures and languages. However, in the case of inter-student speech from the same region, for instance TTU which has Dawan, most of students still use Indonesian and Kupang Malay. Based on this, it can be assumed that regional languages will experience a shift starting from the lexicons that are used the least by the younger generation. These lexicons can be related to nature because the younger generation tends to interact with modern technology and goods. Modernization is also one of the causes of the lack of attention of the younger generation to the natural surroundings. In fact, maintaining the balance of nature must also be their concern as a generation that will carry on the language, culture and customs of the local area.

Relating to eco-linguistics analysis, many researches have been conducted, such as Renjaan [1] who conducted research about the Kei language concerning sea environment through the eco-linguistic point of view with result that the difference picture had caused by (1) the change of sea ecology, (2) there is continuity less from the old people to young people (3) the dominate of Indonesian and Ambon Malay. However, $80 \%$ of Keinese speech community still known and vocalize lexicon orienting in the sea. The maintenance of sea lexicon caused by (1) community source of life, (2) the entity still have in the sea ecology, (3) the intense community interaction with the entity that characterized the sea ecology, and (4) there are local expression that meaning to preserve sea environment. The average understanding rate lexicon is $80 \%$ from 72 informants, Therefore, Keinese speech community still known and vocalize lexicon orienting in the sea in daily occasion.

Besides, Harshini also conducted research about metaphorical expression on Kaghati in Muna language from eco-linguistics perspective with the explanation that in general, metaphors of Muna language constituted by the body of kaghati as the source domain and kaghati's character in the sky or human's behavior or his manner stands as the target domain [2]. The relationship of both was processed in thought of the users, and also respected to the convention of the language community. For example, kaghatiku nobhie fotuno 'my kite is heavy on the head', convey metaphorical meaning 'someone who has a stubborn nature, does not like being advised, or a person who is lazy to think forward to develop their potential.'

Sibarani in doing his research about the eco-linguistics of bamboo in Batak Toba language also find out that the change of life in that society affect the use of language that becomes local wisdom. Relating to bamboo lexicon, that society have less knowledge about it because the existence of practical tools that are being used and also their lifestyle. Based, on those researches, it can be inferred that the damage of environment, change of lifestyle which is part of modernization make local languages becomes in dangerous. Especially for the young generation who are more proud with the use of Indonesian and even more foreign language, the position of regional language, local wisdom and so on will be in final attention.

Eigner Haugen (1972) anchored his eco-linguistic theory in the belief that "The true environment of a language is the society that uses it as one of its codes" as seen in [4]. More, with regard to the environment, Haugen used the concept of the Language Environment in a metaphorical manner, namely the environment is interpreted as a language user community as one of the language codes that can only be used in the minds of speakers, and by language that is only used for use between speakers and the use of speakers with their environment, up Social environment or natural environment. Thus, the ecology of language is determined by people who learn, use and translate the language to others. By Haugen explanation about ecolinguistics, more researches were being conducted to find how the language can influence the sustainability of environment. There are three components in eco-linguistics, they are, (1) ideology: the language is only exist in speaker's mind and it will work if the speakers of that 
language has contact each other naturally in their social and natural lives; (2) psychology: the relation with other languages in speakers' mind; (3) sociology: society in relation as communication media, as seen in [5].

Besides, [6] stated that "the language of advertising can encourage us to desire unnecessary and environmentally damaging products, while nature writing can inspire respect for the natural world. How we think has an influence on how we act, so language can inspire us to destroy or protect the ecosystems that life depends on". Based on those things, it becomes matter that the language itself has really important point in relation of world survival.

\section{Methods}

This research is kind of qualitative research that is used to analyze lexicons in dryland farming. Structured interview and observation were used in collecting data toward forty nine lexicons to fifty Dawanese speakers who live in TTU and TTS of the age between $15-25$ years old. Respondents were chosen by the consideration that most of teenager recently used more Indonesian language in their daily life. So it becomes the main point about their curiosity of their regional language in use. Data was taken by structure interviewed using multiple choice questions about respondents' knowledge relating to the lexicons. Then, data was analyzed by separating and measuring their response between 'know' and 'have no idea' related to the lexicons.

\section{Result and Discussion}

Data has been analyzed shows that respondents understanding relating to the lexicon was in different level. Lexicons about fruits and vegetables were in fairly good category where most responses are 'know and many references' from the respondents

Lexicons

Lexicons

1. /?aen meto?/

2. /?aen ?oek/

3. /?ane? tau(o)/

4. /?aen fini/

5. /foe kase/

6. /fo(u)e kasi/

7. /foe nutu/

8. /laok hawu/

9. /pena?/

10. /penbuka/

11. /laok luli//luli/

12. /nowah/

13. /kuwejaba? Belo/

14. /kofe/ 
15. /fenu/

16. /neke(0)/

17. /?uki/

18. /kiu(yu)/

19. /pauk tob/

20. /?abas/

21. /bako/

22. /?ue/

23. /haumene?/

24. /manus/

25. /no?ek/

26. /piyo mtasa?/

27. /piyo muti? / piyo ?ai/

28. /loil ka'tan/

29. /fue mtasa?/

30. /fue mnanu/

31. /?unus/

32. /kauliman/ /?omla?et/

33. /kaut/ /kauloto?

34. /?okam/

35. /henas/

36. /pnia?/

37. /?ut babkole?//?utamna?u//?utmetan/

38. /?upun/

39. /lelo?

40. /leol muke/

41. /leol mina/

42. /leol boko/

43. /boko/

44. /lilah/

45. /hau kase?//kaut/

46. /?ekkase/

47. /?ekam/

48. /'lak//'jak/

49. /?oben/

50. /kaneh/

As explained before, response for some lexicons that related to kind of trees and commodity of farming were in low category. It becomes very logic due to the environment damage by society and the main used of Indonesian language by the young generation. Typically, for Dawanese in opening the area of gardening for simple reason, they always burn the tree and some kind of plants in that area to plant vegetables or their main food, like rice and corn. Then, 
those burned trees will not change by the new one because it needs long time to grow up. It happens every time in every planting season. It can be predicted that those kind of trees burned to open the gardening area will be unknown by the next generation due to their extinction.

Beside, Kefamenanu and Soe as the capital city of the regency become the center of development living area that give contribution to the damage of environment because in preparing living area, some trees will be cut. Furthermore, the reference about those thing become lost, moreover the use of that words in daily activity will decrease over time significantly.

\section{Conclusion}

Based on data analysis, it can be concluded that the teenagers of Dawanese in general have less knowledge about their language especially related to dryland farming which is one of living resource of Dawanese society. It describes that language maintenance of Dawanese is in bad category. The responds are vary, which is because of less reference related to them and also most of them used Indonesian and even Kupang Malay in their daily. Moreover, it becomes logic because Kefamenanu as the capital city of Timor Tengah Utara regency becomes the center of construction where most of plantation and farming area were destructed for making living or housing area. It affected the loss of ecosystem both plantation and farming which also affect the loss of source can be identified by young generation.

\section{References}

[1] M. Renjaan, "Leksikon Bahasa Kei Dalam Lingkungan Kelautan: Kajian Ekolinguistik," Linguistika, vol. 21, no. 41, pp. 1-24, 2014.

[2] P. Harshini and V. Madhumidha, "International Journal of Linguistics , Literature and Translation ( IJLLT ) ISSN : 2617-0299,” no. Ml, pp. 80-88, 2019.

[3] R. Sibarani, "Pendekatan Antropolinguistik Terhadap Kajian Tradisi Lisan," RETORIKA J. Ilmu Bhs., vol. 1, no. 1, p. 1, Apr. 2015.

[4] P. Bisagni, "Language ecology for the 21st century: linguistic conflicts and social environments," J. Multiling. Multicult. Dev., vol. 37, no. 6, pp. 644-645, 2016.

[5] D. Tualaka, "Bentuk Khazanah Ekoleksikon Pertanian Bahasa Waijewa," Melanes. J. Ilm. Kaji. Bhs. dan Sastra, vol. 1, no. 1, p. 105, 2018.

[6] R. R. Wei, Ecolinguistics: Language, Ecology and the Stories We Live, vol. 36, no. 2. 2018. 